\title{
Legal Requirements for Effective Personal Information Protection through Information Resources Management for Chinese Public Services
}

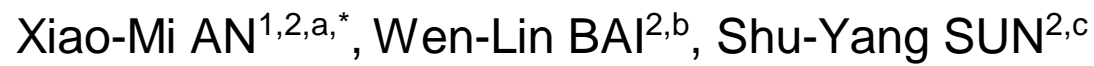 \\ ${ }^{1}$ Key Laboratory of Data Engineering and Knowledge Engineering of the Ministry of Education, \\ Renmin University of China \\ ${ }^{2}$ School of Information Resources Management, Renmin University of China \\ aanxiaomi@ruc.edu.cn, bwenlin-bai@163.com, csunshy33@sina.com \\ ${ }^{*}$ Corresponding author
}

Keywords: Information Resources management, personal information protection, public service.

\begin{abstract}
In recent years, personal information matter that treat people's daily life frequently happens, many studies have been done to deal with it from perspectives of legislation at national level. This paper identifies legal requirements for personal information protection under perspectives of information resources management at organizational level. 29 Chinese laws are identified that have legal requirements for personal information protection for Chinese public services. Studies show that there is an increasing number of legal requirements for personal information protection for key areas of public services. However, there is no independent and comprehensive law for personal information protection along life of information that covers entire processes of information resources management in Chinese legislation. There is a demand for developing comprehensive regime for personal information protection for Chinese public services. This paper suggests three aspects for consideration for the development of a comprehensive regime for personal information protection through information resources management for public services in China. Such suggestions can take the advantages of existed legal requirements for personal information protection as a complementary new whole for an effective regime to overcome existing barriers towards the development of a comprehensive regime for the protection of personal information for the Chinese public services.
\end{abstract}

\section{Introduction}

With rapid development of public services in China, more and more personal information are collected, processed, shared, stored and provision of access to support business collaborative innovation across organizations, to provide value-added reuse for better public services and to promote innovation development of emerging information industry. At the same time, more and more problems of personal information protection come out in many ways in digital environment. In recent years, personal information matter that that treat people's daily life frequently happens e.g. excessive collection of personal information, making personal information public without notice, illegal selling of personal information[1]. To deal with the problems, more and more laws, regulations and standards are developed and are changing to consider both the adoption of new technologies and the protection of personal identifiable information[2][3][4][5]. Much research has been done in China on information privacy, in particular with respect to personal information protection [6][7][8][9][10][11][12]. Such research, however, is mainly conducted from the legal perspective with a focus on the development of appropriate legislations and policies for personal information protection at the national level in existing Chinese literature. There is little research on how specific legislations and polices can actually be implemented in an effective manner and what impacts such legislations and policies have on information resources management (IRM) at organization level. As a result, there is an increasing demand for developing a comprehensive regime to guide an effective implementation of various information privacy legislations and polices at an organizational level in order to adequately protect personal information in today's digitalized environment. 
This paper proposes effective regime for personal information protection through information resources management for public services in China. It identifies legal requirements for personal information protection from existed Chinese laws, the key areas of public services and the key processes of IRM which needs special attention to personal information protection. Key challenging issues of Chinese laws for personal information protection are discussed. To deal with the problems in legal system, development of a comprehensive regime for personal information protection in conformity with Chinese legislation from lifecycle perspective and processes-based information resources management perspective is suggested.

\section{Increasing Legal Requirements for Personal Information Protection}

An investigation of relevant laws, regulations and policies relevant to personal information protection at national level shows that the earliest law relevant to personal information protection was issued in 1979, there are 29 laws relevant to personal information protection from 1979 to 2013. Fig.1 demonstrates that the number of laws is rapidly increasing and amending since 1980s.

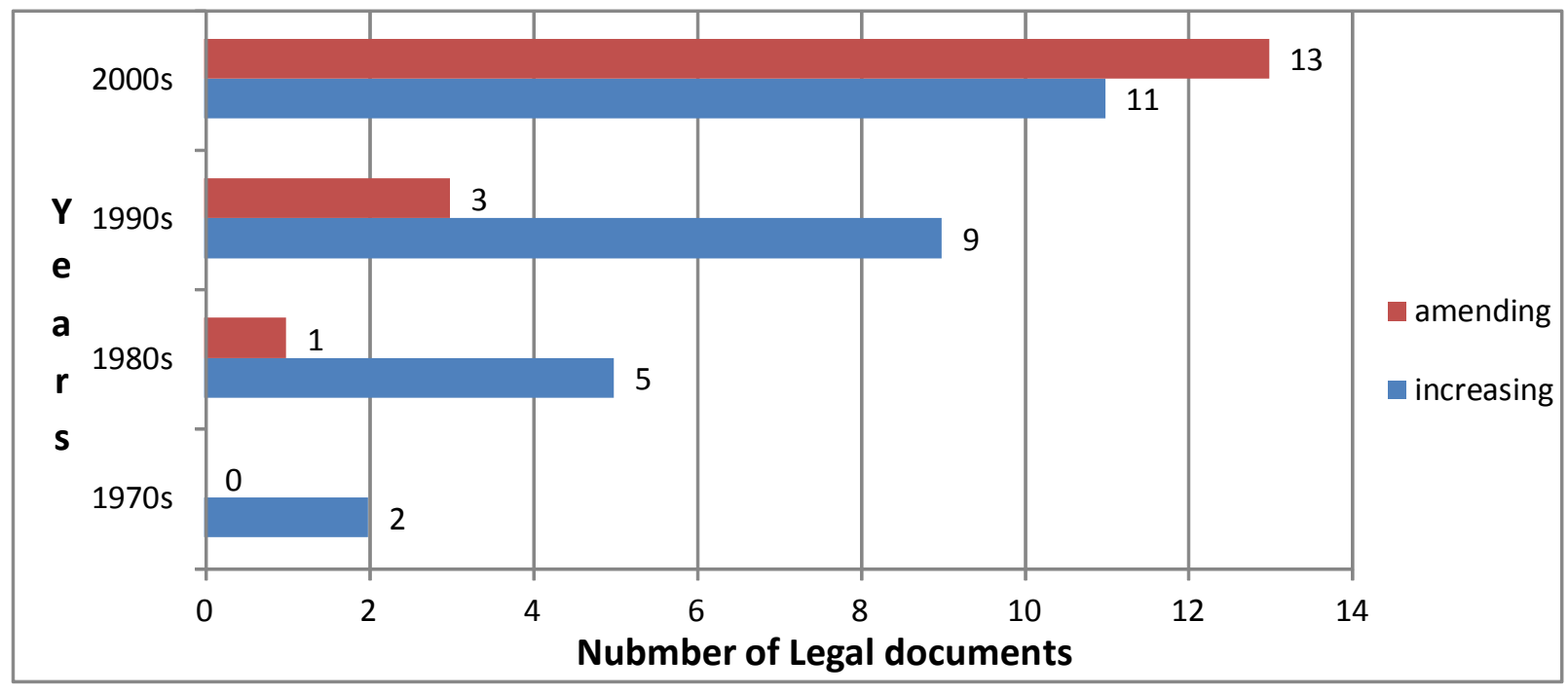

Fig. 1 Number of Legal Documents Relevant to Personal Information Protection

\section{Public Services as Key Area Requiring for Personal Information Protection}

Fig 2 shows that the subjects that have concerns about personal information protection covers multidisciplinary areas including judiciary, finance and insurance, public administration, social security, postal service and communication, medical care, etc. Those subjects are closely relevant to people's daily life. Among the subjects, finance and insurance affairs (6 laws), civil affairs (5 laws), judiciary affairs (4 laws), identification (ID) affairs (3 laws), children affairs (3 laws), rights affairs (3 laws), administrative affairs (3 laws) and security affairs (2 laws) have clear requirements for personal information protection in public services. The result indicates that public services are the key areas that have major concerns about personal information management and need more attention to personal information protection. 


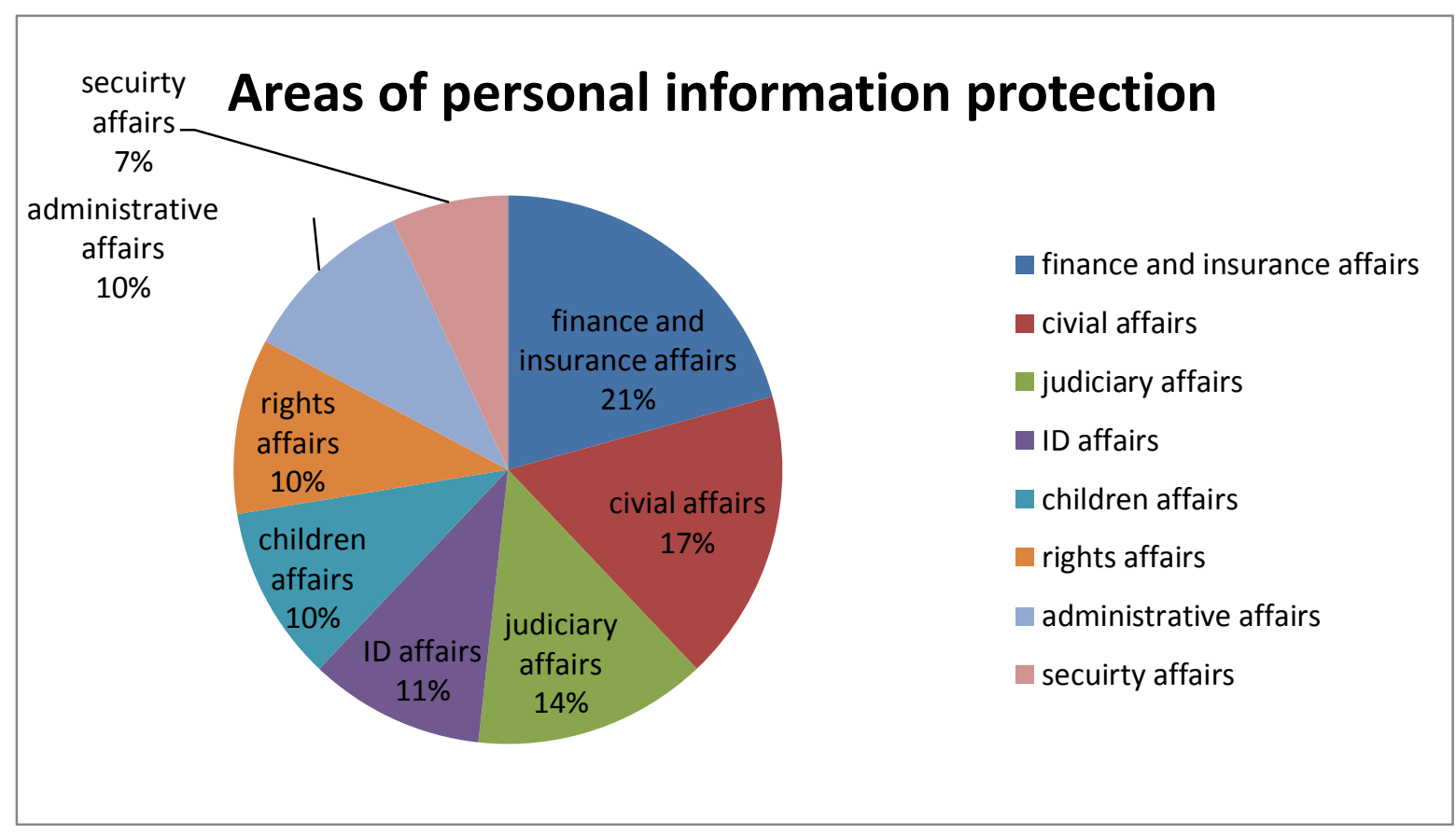

Fig. 2 Subjects of Legal Documents Relevant to Personal Information Protection

\section{Types of Personal Information Requiring for Protection from Chinese Laws}

A critical analysis of Chinese laws shows that though personal information protection has mentioned in the 29 laws, there is no clear definition on what is personal information or what is privacy in any law. However, table 1 shows that five types of personal information are identified for protection from 10 laws. They are identifiable personal information (3 laws), personal identity information (3 laws), personal business and transaction information (3 laws), personal moral right information (1 law) and personal civil rights and interests information (1 law). The results indicate the above types of person information requiring strengthening risk controls in public services.

Table 1 Types of Personal Information Requiring for Protection from Chinese Laws

\begin{tabular}{|l|l|l|l|}
\hline $\begin{array}{l}\text { Types of } \\
\text { personal } \\
\text { identifiable } \\
\text { information }\end{array}$ & $\begin{array}{l}\text { Personal information for } \\
\text { protection }\end{array}$ & Sources ( latest version) & $\begin{array}{l}\text { Number } \\
\text { of laws }\end{array}$ \\
\hline $\begin{array}{l}\text { Identifiable } \\
\text { personal } \\
\text { information }\end{array}$ & $\begin{array}{l}\text { name, address, working } \\
\text { unit, photos, image, } \\
\text { correspondence letters, } \\
\text { dairy, email and other } \\
\text { materials possible to } \\
\text { identify the juveniles }\end{array}$ & $\begin{array}{l}\text { Law of the People's Republic of } \\
\text { China on Prevention of Juvenile } \\
\text { Delinquency,2012, } \\
\text { Law of the People's Republic of } \\
\text { China on the Protection of } \\
\text { Minors,2012, } \\
\text { Criminal Procedure Law of the } \\
\text { People's Republic of China,2012 }\end{array}$ & \\
\hline $\begin{array}{l}\text { Personal identity } \\
\text { information }\end{array}$ & $\begin{array}{l}\text { identity card, passport, } \\
\text { customer identity materials }\end{array}$ & $\begin{array}{l}\text { Passport Law of the People's } \\
\text { Republic of China,2006, } \\
\text { Anti-Money Laundering Law of the } \\
\text { People's Republic of China,2006, } \\
\text { Law of the People's Republic of } \\
\text { China on Resident Identity } \\
\text { Cards,2011 }\end{array}$ & \\
\hline
\end{tabular}




\begin{tabular}{|l|l|l|l|}
\hline $\begin{array}{l}\text { Personal business } \\
\text { and transaction } \\
\text { information }\end{array}$ & $\begin{array}{l}\text { finance transaction records, } \\
\text { medical records, mails }\end{array}$ & $\begin{array}{l}\text { Anti-Money Laundering Law of the } \\
\text { People's Republic of China,2006, } \\
\text { Tort Law of the People's Republic } \\
\text { of China,2009, } \\
\text { Postal Law of the People's Republic } \\
\text { of China ,2012 }\end{array}$ & 3 \\
\hline $\begin{array}{l}\text { Personal moral } \\
\text { right information }\end{array}$ & $\begin{array}{l}\text { women's picture relevant to } \\
\text { reputation, honor, privacy, } \\
\text { portrait and other } \\
\text { personality right }\end{array}$ & $\begin{array}{l}\text { Law of the People's Republic of } \\
\text { China on the Protection of Women's } \\
\text { Rights and Interests ,2005 }\end{array}$ & 1 \\
\hline $\begin{array}{l}\text { Personal civil } \\
\text { rights } \\
\text { interests } \\
\text { information }\end{array}$ & $\begin{array}{l}\text { right to life, the right to } \\
\text { health, the right to } \\
\text { reputation, the right to } \\
\text { honor, the right to portrait, } \\
\text { privacy right, the right to } \\
\text { free choice of marriage, } \\
\text { guardianship, ownership, } \\
\text { real right for usufruct, real } \\
\text { rights granted by way of } \\
\text { security, copyright, patent } \\
\text { right, exclusive right to use } \\
\text { trademark, the right of } \\
\text { discovery, stock right, right } \\
\text { of succession, property right } \\
\text { and interests }\end{array}$ & $\begin{array}{l}\text { Tort Law of the People's Republic } \\
\text { of China,2009 }\end{array}$ & 1 \\
\hline
\end{tabular}

\section{Legal Requirements for Personal Information Protection through IRM Processes}

An investigation of laws that relevant to personal information protection along life of information shows that following activities of IRM have legal requirements: (1) collection (8 items), (2) registration (1 item), (3) security and confidentiality(26 items), (4) access and sharing (3 items), (5) exceptions to access and sharing (26), (6) disposition and custody ( 2 items), (7) penalties (18). Table 2 shows legal requirements for the relevant activities of IRM.

Among the above activities and processes of IRM, security and confidentiality, exceptions to access and sharing and penalties are the key processes that have heavy legal requirements. Studies show that much attention have been paid to establish administrative regime, technology measures and different ways of penalty controls to protect security and confidentiality of personal information. Little attention is paid to the balance between protection and shared access, with special regard to networked public services. It could be seen that the current legal system lacks of holistic approaches to protect personal information which is entire personal information life-cycle controlled. There is a demand for comprehensive legal regime that covers the entire processes and all the activities of IRM along life of personal information.

Table 2 Legal Requirements of Personal Information Protection through IRM Processes

\begin{tabular}{|l|l|l|}
\hline IRM processes & Legal requirements & $\begin{array}{l}\text { Number of } \\
\text { laws }\end{array}$ \\
\hline Collection & $\begin{array}{l}\text { Collection by fair and lawful means , } \\
\text { collection should be limited for specified business functions } \\
\text { and law purpose, } \\
\text { consent of the data subject. }\end{array}$ & 8 \\
\hline Registration & Lawful procedure of registration & 1 \\
\hline
\end{tabular}




\begin{tabular}{|lr|l|l|}
\hline $\begin{array}{l}\text { Security and } \\
\text { confidentiality }\end{array}$ & $\begin{array}{l}\text { professional duty } \\
\text { appropriate security safeguards and classified levels of } \\
\text { security controls, } \\
\text { authorization of access. }\end{array}$ & 26 \\
\hline $\begin{array}{l}\text { Access and } \\
\text { sharing }\end{array}$ & $\begin{array}{l}\text { Lawful procedure in accessing personal information, } \\
\text { nondisclosure of personal information in access and } \\
\text { sharing, } \\
\text { consent of the information subject for lawful and functional } \\
\text { use. }\end{array}$ & 3 \\
\hline $\begin{array}{l}\text { Exceptions to } \\
\text { access } \\
\text { sharing }\end{array}$ and & $\begin{array}{l}\text { Disclosure, sell, and unlawful providing personal } \\
\text { information are not allowed. }\end{array}$ & 26 \\
\hline $\begin{array}{l}\text { Disposition and } \\
\text { custody }\end{array}$ & $\begin{array}{l}\text { Data should be processed fairly and lawfully, } \\
\text { security protection of personal information, } \\
\text { personal information can be retained only to fulfill the } \\
\text { stated purpose, } \\
\text { irrelevant information needs to be securely destroyed. }\end{array}$ & $\begin{array}{l}\text { Order to correct, } \\
\text { pecuniary penalty, } \\
\text { administrative sanction, } \\
\text { criminal punishment. }\end{array}$ \\
\hline Penalty
\end{tabular}

\section{Conclusions and Recommendations}

This paper finds increasing legal demands for personal information protection for Chinese public services. Five types of personal information are identified for protection, including identifiable personal information, personal identity information, personal moral right information, personal civil rights and interests information and personal business and transaction information. Eight key areas of public services which need more attention to personal information protection are identified, including civil affairs, finance and insurance affairs, judiciary affairs, ID affairs, children affairs administrative affairs, security affairs and rights affairs.

The author recommends development of a comprehensive regime for personal information protection through information resources management for public services with special considerations of the following four aspects:

(a) an adequate classification of personal information for risk control with respect to protection of privacy in conformity with Chinese laws,

(b) an appropriate guideline for balance between protection and shared access along the entire life-cycle of personal information with considerations of both the legal requirements for access and sharing, and the exception of access and sharing,

(c) a participatory personal information protection regime for the provision of adequate access to personal information within the context of rapid developments of information technology and networked public services, with respect to dynamic changing of legal requirements from different Chinese laws.

The above suggestions can take the advantages of existed legal requirements for personal information protection as a complementary new whole for an effective regime to overcome existing barriers towards the development of a comprehensive regime for the protection of personal information for the Chinese public services.

\section{Acknowledgement}

This research was financially supported by the Beijing National Social Science Foundation Project 
(Project number: 13ZHB013) and the Fundamental Research Funds for the Central Universities, and the Research Funds of Renmin University of China (Project number:14XNH118).

\section{References}

[1] L, Li, Development Report about Rule of Law in China No. 7 (2009). Social Science Documentation Press, Beijing, 2009.

[2] Decision on Strengthening the Network Information Protection by The Standing Committee of the People's Congress (2012) on http://news.hexun.com/2012-12-28/149603728.html

[3] General Administration of Quality Supervision, Inspection and Quarantine of the People's Republic of China and Standardization Administration of the People's Republic of China .GB/T 25512-2010/ISO 22857:2004. Health informatics - Guidelines on data protection to facilitate trans-border flows of personal, China Standards Press, Beijing, 2011.

[4] General Administration of Quality Supervision, Inspection and Quarantine of the People's Republic of China and Standardization Administration of the People's Republic of China. GB/Z28828-2012.Personal Information Protection Guidelines for Public and Commercial Service Information System of Information Security Technology, China Standards Press, Beijing, 2012

[5] Regulations on the Telecom and Internet Users' Personal Information Protection (2013) on http://www.miit.gov.cn/n11293472/n11293832/n12843926/n13917072/15514067.html

[6] H. Zhang, Research Front of Personal Information Protection. Law Press, Beijing, 2006.

[7] P. Xia, J. Wang, W. Zhou, IT Development and Personal Information Protection, Economic Daily Press, Beijing, 2007.

[8] P. Jiang, Personal Data Information Protection by Laws, Chinese University of Political Science and Law University Press, 2008.

[9] Q. Liang, et al. Introduction to Personal Information Protection. People's Press, 2008.

[10] L. Kong, Privacy Protection of Personal Data. Wuhan University Press, Wuhan, 2009.

[11] H. Hong, Personal Information Civil Law Protection, Law Press, Beijing, 2010.

[12] Y. Yao, Personal Information Protection from the Constitutional Perspective. Law Press, Beijing, 2012. 